\title{
WHAT NEXT?
}


To Gavin, Clemency and Toby who went away and played somewhere else, my love and thanks. 


\section{WHAT NEXT?}

\section{Post-basic Opportunities for Nurses}

\section{Jill Baker}

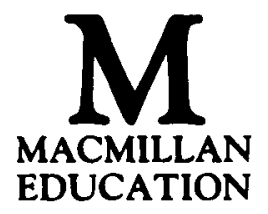


(C) Jill Baker 1988

All rights reserved. No reproduction, copy or transmission of this publication may be made without written permission.

No paragraph of this publication may be reproduced, copied or transmitted save with written permission or in accordance with the provisions of the Copyright Act 1956 (as amended), or under the terms of any licence permitting limited copying issued by the Copyright Licensing Agency, 33-4 Alfred Place, London WC1E 7DP.

Any person who does any unauthorised act in relation to this publication may be liable to criminal prosecution and civil claims for damages.

First published 1988

Published by

MACMILLAN EDUCATION LTD

Houndmills, Basingstoke, Hampshire RG21 2XS

and London

Companies and representatives

throughout the world

Typesetting by Footnote Graphics,

Warminster, Wilts.

British Library Cataloguing in Publication Data

Baker, Jill

What next? : post-basic opportunities for

nurses.

1. Great Britain. Medicine. Nursing-

Career guides

I. Title

$610.73^{\prime} 023^{\prime} 41$

ISBN 978-0-333-44784-0

ISBN 978-1-349-09728-9 (eBook)

DOI 10.1007/978-1-349-09728-9 


\section{Contents}

Apologia and Acknowledgements

Abbreviations Used in the Text

viii

Foreword

1 Introduction 1

2 Planning Your Career 3

3 Project 2000 21

4 Further Statutory Training 27

5 Midwifery 31

6 Nursing in the Community 39

7 Post-basic Clinical Specialties $\quad 55$

8 Higher Education $\quad 61$

9 Teaching $\quad 79$

10 Management $\quad 89$

11 Distance Learning 95

12 But It's Not Like That at All ... 109

Useful Addresses 111

Further Reading 119

Index 


\section{Apologia and Acknowledgements}

Throughout this book I have referred to nurses as 'she'. This is simply to avoid the use of 'he and she', 'his and her' and similar expressions, and it is in no way intended to insult the many caring men in the profession. I hope that they will forgive me.

I gratefully acknowledge Mary Waltham for her unfailing encouragement, and Pat Stillwell and Kathy Smithers for their practical help without which this book would have never been written. 


\section{Abbreviations Used in the Text}

$\begin{array}{ll}\text { AIDS } & \text { Acquired Immune Deficiency Syndrome } \\ \text { BA } & \text { Bachelor of Arts } \\ \text { BN } & \text { Bachelor of Nursing } \\ \text { BSc } & \text { Bachelor of Science } \\ \text { CPN } & \text { Community Psychiatric Nurse } \\ \text { CSE } & \text { Certificate of Secondary Education } \\ \text { DENCert } & \text { District Enrolled Nurse Certificate } \\ \text { DHSS } & \text { Department of Health and Social Security } \\ \text { DLC } & \text { Distance Learning Centre } \\ \text { DNCert } & \text { District Nursing Certificate } \\ \text { EN } & \text { Enrolled Nurse } \\ \text { ENB } & \text { English National Board for Nursing, Midwifery and } \\ & \text { Health Visiting } \\ \text { GCE } & \text { General Certificate of Education } \\ \text { GCSE } & \text { General Certificate of Secondary Education } \\ \text { GP } & \text { General Practitioner } \\ \text { MA } & \text { Master of Arts } \\ \text { MPhil } & \text { Master of Philosophy } \\ \text { MSc } & \text { Master of Science } \\ \text { NHS } & \text { National Health Service } \\ \text { OHNC } & \text { Occupational Health Nursing Certificate } \\ \text { OND } & \text { Ophthalmic Nursing Diploma } \\ \text { PCAS } & \text { Polytechnic Central Admissions System } \\ \text { PhD } & \text { Doctor of Philosophy } \\ \text { RCN } & \text { Royal College of Nursing } \\ \text { RGN } & \text { Registered General Nurse } \\ \text { RHV } & \text { Registered Health Visitor } \\ \text { RM } & \text { Registered Midwife } \\ \text { RMN } & \text { Registered Mental Nurse } \\ \text { RNMH } & \text { Registered Nurse for the Mentally Handicapped } \\ \text { RNT } & \text { Registered Nurse Tutor } \\ \text { UCCA } & \text { Universities' Central Council on Admissions } \\ \text { UKCC } & \text { United Kingdom Central Council for Nursing, Mid- } \\ & \text { wifery and Health Visiting } \\ & \end{array}$




\section{Foreword}

In an age where there is an ever-increasing demand for efficient, effective use of resources and public accountability, the need for nurses to plan their career development has never been more urgent. Gone are the days when a basic training sufficed to see the kindly carer through the rest of his or her working life. There is an explosion of new information which is growing all the time, and in order to be able to offer patients the service which they deserve, nurses have to be aware of new developments and continue to learn throughout their professional careers. This is no more than one would expect of any person working in a service-related discipline, but especially important when the 'product' of the service is another human being who has a right to know that the care that is offered is based on sound, up-to-date understanding.

Partly because of the diversity of choices which are open to nurses once they have undertaken their basic preparation, it is not always easy to know which options are available, or the implications of choosing a particular career path. A text such as this, which collates information about these choices, can be a valuable resource when important decisions are made about where to go next. Not only is information provided about formal access to courses, but also something about the work itself and the implications of moving into a particular sphere of nursing.

While information has been collected here about the more formal aspects of career development, it is worth remembering that learning is not confined to the addition of formal qualifications to one's repertoire. One of the important characteristics of all professional people is that they have a curiosity about their work and continue to question and, at times, challenge current practice through self-directed enquiry. Such a characteristic does not have to be confined within the boundaries of a formal course but is an activity which should invade practice at all times.

A combination of both formal and informal enquiry is widely 
supported at both national and local levels as evidenced by the recent DHSS video $A$ Way of Thinking and its accompanying text. It is recognised that the decisions which nurses have to make about their future careers are not easy, but a wise choice can lead to a rewarding future.

\section{Barbie Vaughan \\ Senior Tutor \\ Clinical Practice Development Team John Radcliffe Hospital School of Nursing Oxfordshire Health Authority}

